\title{
Hylectbrus rubi Saunders, 1850 - a new species of strepsipteron (Insecta: Strepsiptera: Stylopidae) in the fauna of Belarus
}

\author{
Hylecthrus rubi Saunders, 1850 - новый вид веерокрылых \\ (Insecta: Strepsiptera: Stylopidae) в фауне Бекаруси
}

\author{
A.M. Ostrovsky \\ A.M. Островский
}

Gomel State Medical University, Lange Str. 5, Gomel 246000 Belarus. E-mail: Arti301989@mail.ru. Гомельский государственный медицинский университет, ул. Ланге 5, Гомель 246000 Беларусь.

Key words: Hylecthrus rubi, finding, fauna, Belarus.

Ключевые слова: Hylecthrus rubi, находка, фауна, Беларусь.

Abstract. Hylecthrus rubi Saunders, 1850 (Strepsiptera: Stylopidae) is firstly recorded in Gomel Region of Belarus near Gomel city as a parasite of bee Hylaeus (Hylaeus) communis Nylander, 1852 in July 2019. Brief information on distribution and ecology of the species is given.

Резюме. Веерокрылое Hylecthrus rubi Saunders, 1850, вид из семейства Stylopidae, найденный в окрестностях города Гомель на Hylaeus (Hylaeus) communis Nylander, 1852 в июле 2019 года, впервые отмечен для фауны Беларуси. Приведены краткие данные по распространению и экологии вида.

\section{Introduction}

Members of the order Strepsiptera display highly peculiar morphology and lifestyles. They are small to medium sized insects (1.0-7.5 mm long) exhibiting extreme sexual dimorphism [Kinzelbach, 1971a; Kathirithamby, 1989]. Free living and flying males have twisted hind wings, while their fore wings are reduced to clublike appendages. Usually endoparasitic and wingless females are known to colonize members of seven insect orders [Kathirithamby, 1989, 2009]. Approximately 600 Strepsiptera species are known to exist globally [Kathirithamby, 2002; Kinzelbach, Pohl, 2003], while 30 species from 7 families are known in Europe [Pohl, 2010; Soon et al., 2011]. There are 3 species registered in Belarus [Medvedev, 1965; Ostrovsky, 2018, 2019]. Continuing our research, the Hylecthrus rubi Saunders, 1850 has been found in Belarus.

\section{Results}

\author{
Strepsiptera \\ Stylopidae Kirby, 1813 \\ Stylopinae Kirby, 1813 \\ Hylecthrus rubi Saunders, 1850 \\ Fig. 1.
}

Material. Republic of Belarus, Gomelskaya Oblast, near Gomel city, floodplain meadow in the valley of the Iput River, 21.07.2019 - 1 to of Hylaeus (Hylaeus) communis Nylander, 1852 stylopized by female of H. rubi. A.M. Ostrovsky leg. et det.
Distribution. Widely distributed in Europe and extending to the Near East, currently known from Albania, Austria, Bulgaria, Croatia, French mainland, Germany, Great Britain, Greek mainland, Hungary, Italian mainland, Romania, Sicily, Slovakia, Slovenia, Spanish mainland, Switzerland, Ukraine [Pohl, 2010].

Notes. H. rubi is a typical parasite of many Hylaeus Fabricius, 1793 (Hymenoptera: Colletidae) species [Medvedev, 1965; Kinzelbach, 1971b]. However, from Belarus only $H$. (H.) communis has been recorded as its host. In Belarus $H$. (H.) communis is a widespread and common species.

\section{Conclusion}

A strepsipteron species Hylecthrus rubi Saunders, 1850 and genus Hylecthrus Saunders, 1850 from the family Stylopidae is described for the fauna of Belarus for the first time. From Belarus only $H$. (H.) communis has been recorded as its host of $H$. rubi.

\section{References}

Kathirithamby J. 1989. Review of the Order Strepsiptera // Systematic Entomology. Vol.14. P.41-92.

Kathirithamby J. 2002. Strepsiptera. Twisted-wing parasites. Version 24 September 2002 (under construction). - The Tree of LifeWeb Project. Available at http://tolweb.org/ Strepsiptera/8222/2002.09.24 (accessed 5 February, 2019).

Kathirithamby J. 2009. Host-Parasitoid Associations in Strepsiptera // Annual Review of Entomology. Vol.54. P.227-249.

Kinzelbach R.K. 1971a. Morphologische Befunde an Fächerflüglern und ihre phylogenetische Bedeutung (Insecta: Strepsiptera) // Zoologica. H.119. S.1-256.

Kinzelbach R.K. 1971b. Redescription and revision of the Strepsiptera genus Hylecthrus Saunders, 1850 // Angewandte Parasitologie. Jg.12. H.4. S.204-220.

Kinzelbach R.K., Pohl H. 2003. Ordnung Strepsiptera, Fächerflüger // Wirbellose Tiere. 5. Teil: Insecta. Heidelberg-Berlin: Spektrum Akademischer Verlag. S.526-539.

Klaus M. 2016. Über Fächerflügler (Strepsiptera) bei Hautflüglern (Hymenoptera) in Franken und darüber hinaus // Galathea. Bd.32. S.83-99.

Medvedev L.N. 1965. [The order Strepsiptera] // Keys to the insects of the European part of the USSR. Coleoptera and Strepsiptera. M.-L.: Nauka Publ. Vol.2. P.641-645. [In Russian]. 

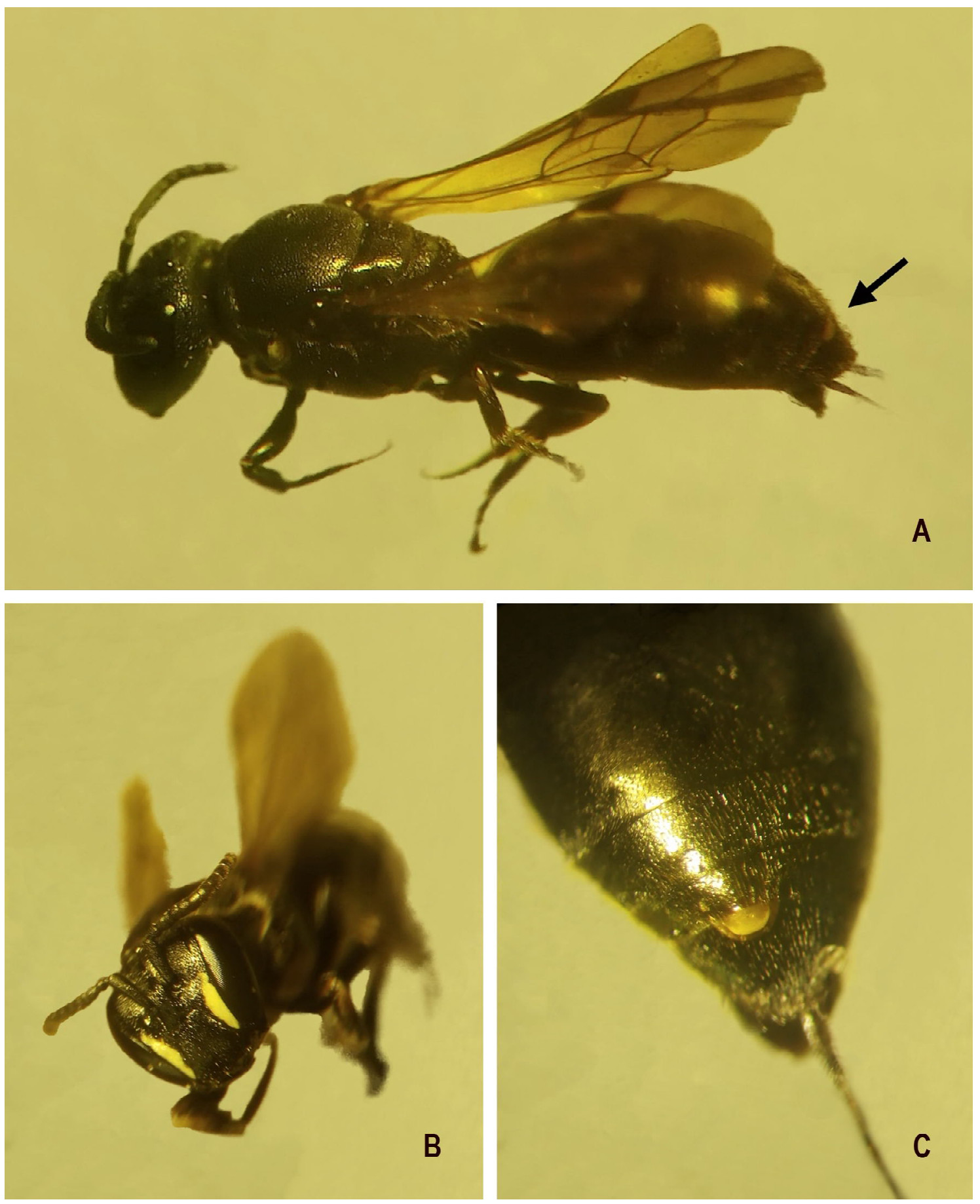

Fig. 1. A, B - Hylaeus (Hylaeus) communis Nylander, 1852: specimen (female) stylopized by a female of Hylecthrus rubi Saunders, 1850; C - posterior dorsum of female H. (H.) communis showing female of H. rubi exserted at posterior border of gastral tergums $\mathrm{V}$ and $\mathrm{VI}$.

Рис. 1. A, В - Hylaeus (Hylaeus) communis Nylander, 1852: экземпляр (самка), стилопизированный самкой Hylectbrus rubi Saunders, 1850; С - конец брюшка самки Н. (Н.) communis с самкой Н. rиbi на задней границе V и VI тергитов брюшка.

Ostrovsky A.M. 2018. A first record of Stylops melittae Kirby, 1802 (Insecta: Strepsiptera: Stylopidae) in Belarus // Euroasian entomological journal. Vol.17. No.3. P.189-190. DOI: 10.15298/euroasentj.17.3.08.

Ostrovsky A.M. 2019. A new record of strepsipteron Paraxenos sphecidarum (Dufour, 1837), (Insecta, Strepsiptera: Xenidae) from Belarus // Euroasian entomological journal. Vol.18. No.3. P.186-187. DOI: 10.15298/euroasentj.18.3.07.

Pohl H. 2010. Fauna Europaea: Strepsiptera. Fauna Europaea, ver. 2.4. Available at http://www.faunaeur.org (accessed 5.02.2019). Soon V., Kesküla T., Kurina O. 2011. Strepsiptera species in Estonia // Entomologica Fennica. Vol.22. P.213-218. 